\title{
Geographies of Landscape: Representation, Power and Meaning
}

\begin{abstract}
Green criminology has sought to blur the nature-culture binary and this paper seeks to extend recent work by geographers writing on landscape to further our understanding of the shifting contours of the divide. The paper begins by setting out these different approaches, before addressing how dynamics of surveillance and conquest are embedded in landscape photography. It then describes how the ways we visualize the Earth were reconfigured with the emergence of photography in the nineteenth century and how the world itself has been transformed into a target in our global media culture.
\end{abstract}

\section{KEYWORDS}

Criminology, Culture, Geography, Nature, Photography

The last twenty years have seen the emergence of two distinct perspectives in criminology: green criminology and cultural criminology. The potential for convergence was identified early on by South (1998) in his account of green cultural politics, in White's (2002) linking of environmental harm to the political economy of capitalist consumption, and in Brisman's (2010) analysis of the criminalization of environmentally beneficial activities. More recently, there have been attempts to develop green cultural criminological perspectives to understand the significance of various representations of environmental crime and harm (e.g., Brisman, 2017; Brisman and South, 2013, 2014; Ferrell, 2013; Natali, 2016; South, 2017). This paper seeks to add to these efforts by addressing the 'spatial turn' that has been so pronounced across disciplines ranging from anthropology to religious studies (Hayward, 2012:443). Yet, given that space is one of the defining units of criminological analysis, it has occupied a strangely passive role in the discipline - the stage on which the drama unfolds - and this is indicative of the Kantian separation of geography from history, where the former is defined in relation to 'description and space' and the latter to 'narration and time' (Mitchell, 2011:72). In this paper, I want to consider the 'agency of space' and the kind of 'imaginative geographies' (Gustafsson, 2013:149) that emerge from the close scrutiny of landscapes.

For most geographers, landscape is a core idea, as it speaks to one of the discipline's defining interests, which is the relationship between the natural environment and human society, in all its bewildering complexity. This paper begins by setting out these arguments in more detail, before turning to how the medium of photography offers distinctive ways of seeing the global consequences of the use and abuse of landscape. The photography of place has become increasingly political, not just in terms of documenting destructive environmental change, but in thinking through the very politics of representation. Although many ecologically orientated artists are 'aware of local-global connections, few artists are equipped to do more than comment on them' (Lippard, 1997:183) and are frequently condemned for making pictures as sublimely beautiful as their predecessors, even when they focus on climatic catastrophes (see generally Brisman this issue). Consequently, this paper is not especially concerned with a history of nature and the landscape, but rather with how geography connects us to what the photographer John Gossage calls the 'past as present' (quoted in Badger, 2014:161) —a radical reversal of what photography normally does. 
Of course, recent developments in visual criminology (charted in Brown and Carrabine, 2017) have also drawn attention to how images are shaping the social world and the discipline itself. From this perspective, important work has emerged exploring carceral landscapes (Moran, 2015; Schept, 2015; Story, 2016) and has challenged criminology to confront how it understands to the question of colonialism (Cunneen and Tauri, 2016). I have also sought to examine the dynamic of spectacle and surveillance, the mixing of means of communication with those of destruction, in modern forms of warfare (Carrabine, forthcoming). This paper builds on these developments and addresses the nature of landscape. For Stephen Daniels, the potential of the term 'landscape' arises from its 'duplicity' - 'not despite its difficulty as a comprehensive or reliable concept, but because of it'; the implication is that we 'should beware of attempts to define landscape, to resolve its contradictions; rather we should abide in its duplicity' (quoted in Matless, 2014:6). In a series of influential publications, David Matless $(1998,2014,2017)$ has drawn out the tensions between different 'cultures of landscape' and how they forge certain forms of human conduct, weaving through more temporal processes of history and memory. The 'duplicity' of landscape is what gives it such analytical purchase, conveying 'depth and surface, solid earth and superficial scenery, the ontological and the ideological', yet 'impossible to place on either side of a dualism of nature and culture' (Matless, 1998:12). Green criminology has sought to blur the nature-culture binary and this paper seeks to extend recent work on geographies of landscape to further our understanding of the shifting contours of the divide.

\section{Horizons}

Landscape has long been closely associated in geography with culture- 'the idea of visible forms on the earth's surface and their composition' (Cosgrove, 1988/2008:178, emphasis in original) - and so for some, landscape is a text to be read, inseparable from signifying practices enabling us to make sense of our worlds, while others push the metaphor further, revealing how landscapes are authored, made and orchestrated for the spectacle of human life. In contrast, different approaches attend to how landscapes are produced by the material power dynamics of capitalist accumulation and result from basic inequalities between the classes. A leading exponent of this more Marxist understanding of social relations is Don Mitchell (1996), who has explored how the picturesque Californian landscape masks the significant amount of struggle, toil and hard work that lies behind the scenes, especially as rooted in the exploitative agricultural industry built on the backs of migratory labour. In fact, much of the work performed by landscape is an on-going process of hiding that fundamental feature of exploitation, by naturalising it and legitimating certain kinds of landownership.

Of course, it is not just unequal class relations that are sustained through representations of landscape; so, too, are relations of gender, nation, sexuality, and race experienced and expressed through enduring social processes. To take gender, Gillian Rose (1993) subjected human geography to withering critique, exposing the overarching masculinism in the discipline and noting how the tradition of visuality in it (learning from looking in the field) has frequently led to the conflation of seeing with knowing. Fieldwork is condemned for creating a distance between the viewer and viewed, associating it with a problematic male gaze, so that in 'geographical discourse, landscapes are often seen in terms of the female body and the beauty of Nature' (Rose, 1993:87). Connected to this privileging of masculine over feminine knowledge is the construction of a culture-nature dualism that pervades both social science and aesthetic writing, while Rose's notion of 'paradoxical space' has opened 
new ways of acknowledging the difference of others (Mahtani, 2001) and non-human animals (Goyes and Sollund, this issue; Sollund, 2017).

Difference in all of its many, and frequently intersecting, forms is tied closely to issues of access - where questions of belonging and exclusion assume significant spatial dimensions. The work of Frantz Fanon, bell hooks, Edward Said, and Gayatari Spivak are among the thinkers highlighting diverse processes of othering, positionality and situated knowledges; it remains the case, however, that 'geographers have still to break out of the tradition of fetishizing the margins and ignoring the centre' (Hopkins and Pain, 2007:287). Of course, geography has played a pivotal role in imperialism (Godlewska and Smith, 1994) and diffusing a colonial logic of the world (Blaut, 1993). Whether it was through the bible or the bayonet, western powers exercised control over conquered territories and geographical knowledge was intimately tied to the project of empire (Driver, 2000). There have been many attempts to examine critically these relationships and here I concentrate on one significant strand exploring the ties between imperialism-understood as the practice of wielding political and economic control over foreign territories - and the constitution of landscapes in them. In so doing, I draw inspiration from W.J.T. Mitchell's (2002a:7) influential essay on 'Imperial Landscape', which questioned three fundamental assumptions that he termed 'the "Western-ness" of landscape, its modernity, and its visual/pictorial essence'.

The uniquely European modernity of landscape representation is undermined by the ways non-Western imperial powers have themselves developed strong landscape traditions. Ancient Chinese landscape painting flourished during the height of Chinese imperial power and only began to decline in the eighteenth century, just as China was becoming an object of 'English fascination and appropriation at the moment when England was beginning to experience itself as an imperial power', suggesting that landscape aesthetics might best be regarded as 'the "dreamwork" of imperialism' (Mitchell, 2002a:9-10). Mitchell's essay was originally published in a collection he edited in the early 1990s and had a major impact on how the power of landscape can be conceptualised, yet as he subsequently noted this is a 'subtle power over people' and it is this very 'indeterminacy of affect' that is 'a crucial feature of whatever force landscape can have' (Mitchell, 2002b:vii). Such a recognition resonates with developments in geography that include an emerging commitment to nonrepresentational (Thrift, 2008) or more-than-representational (Lorimer, 2005) theory, which offers ways of engaging with the visual that explores the tacit, sensory, habitual and affective aspects of experiencing space that rarely feature in more traditional, representational geography. The implications of these arguments were initially raised by Keith Hayward (2012) in criminology and have been developed by Nadera Shalhoub-Kevorkian (2017) in her account of colonial violence in occupied East Jerusalem.

Seeing is not the only way we sense landscape, and recent attention has focussed on how the body dwells in it, so as to explore 'the nexus of materiality, corporeality and perception' (Wylie, 2007:178) that produce the feelings and sensations embedding us in the landscape as we move through it. Shifting from representation to practice and performance offers an alternative to more static approaches, conveying something of the 'ineffability of being in landscape' (Horton and Kraftl, 2014:117). These newer phenomenologies have enlarged the reach of landscape studies in geography, but there remains some concern over them. As one critic put it:

My wariness about abstract accounts of body practices and the return to phenomenological notions of "being-in-the-world" arises also from the 
danger...that they constitute a retreat from feminism and the politics of the body in favour of the individualistic and universalizing sovereign subject.

(Nash, 2000:662)

What unites this scholarship is the understanding that landscapes have a particular kind of performative power. As Mitchell (2002c:1) announces at the outset, the ambition 'is to change "landscape" from a noun to a verb. It asks that we think of landscape, not as an object to be seen or a text to be read, but as a process by which social and subjective identities are formed'.

The approach focuses not simply on what a landscape 'is' or 'means', but what it 'does'how representations work as a dynamic, cultural force. A point well demonstrated by Anne Adams (2002), explaining how a naturalistic landscape aesthetic first developed in Holland in the seventeenth century because of a radical ecological transformation (an extraordinary land reclamation project physically creating the Netherlands from the sea) combined with political, economic and religious upheavals that forged a striking and distinctive relationship for the Dutch with their land and property. In her account, Dutch landscape painting provided a telling site for the making of new-and rival-communal identities in a developing commercial nation. As she puts it, the "visual preoccupation with the landscape must have served an important function for a population constantly threatened with ruin by the sea, providing a form of imaginative control over nature that daily threatened destruction of all that the people had created' (Adams, 2002:65). This more active way of thinking emphasises both the ideological and phenomenological dimensions of how landscapes, of all sorts, influence and shape us.

Denis Cosgrove was one of the leading geographers exploring how social power is reproduced through landscape. Writing in the late 1990s, he noted how environmentalist criticism of modern social formations was noticeably absent in his earlier work, acknowledging that the theoretical framework on which it rested had largely failed to develop a 'coherent theory of the natural world or of social relations within it'. Doubting whether he 'would even today give great prominence to environmentalism', he asserted:

Any sensitivity to the history of landscape and its representations in the Western tradition forces the recognition that human history is one of constant environmental modification, manipulation, destruction and creation, both material and imaginative. And guiding, if rarely driving, this process is the beliefdeposited deep in myth and memory - that the good, the true and the beautiful, as well as the threatening, the awesome and the disgusting, are inscribed in the contours of the land.

(Cosgrove, 1998/2008:37)

These comments on the mythic culminated in his Apollo's Eye: A Cartographic Genealogy of the Earth in the Western Imagination, in which Cosgrove traced representations of the globe from antiquity to the space age. Using the iconic 'blue marble' image of the earth seen from space, Cosgrove (2001) argued that once this image was published in 1972, our understanding of the world and our place in it changed quite dramatically. Yet his point was that human attempts to represent Earth have a long history, which he linked to changing conceptions of Western identity to reveal the deep roots of contemporary global thinking. Crucial to the 'Apollonian gaze', Cosgrove (1998/2008:xi) explained, is the way it 'seizes divine authority for itself, radiating power across the global surface from a sacred center, 
locating and projecting human authority imperially towards the ends of the earth'. These dynamics of surveillance and conquest are embedded in landscape photographs of the West and in the next section I describe how the ways we visualize the Earth were reconfigured with the emergence of photography in the nineteenth century.

\section{Frontiers}

From its inception in the mid-nineteenth century, photography established itself as a triumph of scientific progress and, like the invention of the steam train, the technology transformed conventional understandings of space and time. Initial responses to the medium were characterized by a 'mind-numbing puzzlement about what photography was and how photographs stood in relation to the picture-making tradition' (Snyder, 2002:175). Many were struck by the mechanical ability of the apparatus to record authentically objects or scenes in photographic prints. Running counter to this emphasis on literal, optical truth, there existed an insistence on the camera's magical 'capacity to express something beyond the surface appearance of things' allowing 'us to see what we would not otherwise see' (Clark, 1997:20). Photography continued to be haunted by this persistent tension between science and art, oscillating between 'faith in the objective powers of the machine and a belief in the subjective, imaginative capabilities of the artist' (Sekula, 1981:15). Landscape photography, more than any other genre, was wedded to the conventions of academic painting and the traditions of landscape art-as had developed in Holland and then in England during the eighteenth century. Indeed, the word landscape, in English, was originally used to describe a genre of Dutch painting and only later came to refer to the wider idea of a view or prospect (Bright, 1985). By the nineteenth century, the landscape was understood through a sophisticated and popular picturesque aesthetic.

Landscape was viewed not so much in terms of its natural, elemental features, but rather through idealised 'images of a rural idyll quite at odds with reality' that sought 'visual confirmation of a timeless Arcadia; a unified image of social life' (Clark, 1997:55). The early landscape photographers worked within these conventions, but by the 1860 s, new terms of reference were devised, especially in the United States, which departed from those inherited from painting. As Joel Snyder (2002) explains, a large and distinct market for landscape photography (through publishing houses, tourism and stereographs) developed to meet the demands of a growing middle-class audience. Especially important were the railroad companies, eager to promote the scenic spectacle of their routes to urban customers. Most of the celebrated photographers from the post-Civil War era, including the likes of Carleton Watkins, Eadweard Muybridge, William Henry Jackson, Frank Haynes and Charles Savage, worked for the railroads either as direct employees or on specific commissions, and were crucial in promoting the uplifting grandeur of 'wild' nature in the Great West.

The stereograph introduced new ways of deriving pleasure from protracted scenic viewing (Krauss, 1982:314), bringing an almost cinematic experience into the middle-class American home. The extent of this national market has been described as follows:

On their travels, tourists sought out the spectacular features they had already been shown in pictures: giant redwoods, spewing geysers, precipitous canyons, majestic mountains, and painted deserts. On an industrialized scale never before realized, scenery was commodified, packaged, and sold to a mass public, its consumption a sign of leisure and status, indicating the ability to take time off from the industrial work schedule of school and office, the disposable resources 
to pay for the railroad tickets and accommodations, and the taste and cultivation to appreciate the spiritual pleasures to be had. The Great West embodied the antithesis of urban, industrial life, with its ethnic and class divisions, dirt, moral degeneracy, intractable criminality, feminization, dependent children, poverty, social contracts, compromises, and the pervasive subservience to oppressive bureaucratic structures.

(Bright, 1992:61)

Geographical expeditions to the western territories were also pivotal to the development of frontier culture iconography, where the production of graphic material to enable resource extraction, military control, and scientific understanding were used for the purposes of development and settlement. The surveys were indicative of the necessity to bring such a vast area of land under political and cultural control.

The pictures steer clear of questioning whose land it is and never wonder about the original inhabitants forcibly removed or brutally decimated in the land that had been theirs just decades before. Many of the photographs encourage a belief in a western American Eden, offering an 'awed stare into a landscape that is unmarked, unmeasured, and wild' (Snyder, 2002:196). William Henry Jackson stands as a defining figure in this instance and his 'Grand Canyon of the Colorado' (1883) (Figure 1) <Figure 1 near here> is among his most famous images, distilling elements of what has come to be defined as the American picturesquesublime. Enormous in scale, the two human figures at the centre of the picture are engulfed by a rocky outcrop: one reclines in 'the typical pose of a tourist enjoying the scene, while the other uses a telescope', suggesting 'the two extremes (aesthetic and scientific) of the American landscape tradition' (Clark, 1997:60). The image also conveys an underlying spiritual mood of manifest destiny - that this land is 'God's country and, coincidentally, that of the railroads, real estate, and mining interests as well' (Snyder, 2002:198).

Deborah Bright (1992:61) has also noted how Jackson's celebrated views of Yellowstone's geothermal features were decisive in convincing Congress to establish the first national park in 1872, but this legislation "was powerfully backed by railroad interests that owned most of the tourist concessions and rights of way'. Such images underline the extent to which landscape photography was bound up with the larger project of defining and commemorating a vision of nationhood and freedom, reinforcing dominion over the land and its resources. Indeed, colonialism established new spaces and modalities of property distribution. The 'frontier' is clearly a political project and settler colonial concept, where the 'survey' and the 'property relations that it helped reconstitute, also had a particular relation to state violence' (Blomley, 2003:128), as we shall see shortly.

In the twentieth century, an idealised aesthetic was further popularised by the Californian landscape photographers Edward Weston and Ansel Adams. Both played essential roles in constructing the American landscape as a dramatic, pristine wilderness, with no trace of human presence, thereby evoking a mysterious and transcendental otherness. Weston's (1936) 'Dunes, Oceano (The Black Dome) is such an example, which takes an inhospitable American terrain and emphasizes abstract textures, imbuing a barren environment with an expressive beauty. Likewise, Adams set out a vision of the picturesque-sublime in images like 'Moon and Mount McKinley' (1948), which is among his most famous, and sustains a sense of awe through the different elements in the composition- land, cloud, water and sky - that imply the endless sweep of nature. These epics remain unsurpassed in mass culture, not least because they 'played well as a familiar and comforting respite from images 
of the 1930s Dust Bowl, as well as the newer, more unfathomable horrors of Buchenwald and Hiroshima' and helped to depoliticize Cold-War era US western expansion (Bright, 1992:64). In contrast to the urban American documentary tradition, which saturated the photograph with human activity, these landscape images are devoid of any human presence.

It was only in the last quarter of the twentieth century that these idealised depictions of the pristine sanctity of the wilderness came to be seen as pure fantasies incapable of speaking to the political realities of the moment. Contemporary photographers came to regard Ansel Adams as the 'unwitting embodiment of the false dichotomy between humanity and nature at the root of our continuing legacy of environmental destruction' (Spaulding, 1998:xiv). A large part of the delay in critically confronting these consequences was 'the enduring appeal of the romantic "wild nature" aesthetic in conservationist circles as well as popular media' (Bright, 1992:64). As Brisman (2017:524) notes, a crucial turning point was the seminal exhibition, 'New Topographics: Photographs of a Man-Altered Landscape', mounted by William Jenkins at the International Museum of Photography at George Eastman House in Rochester, New York, in 1975. Jenkins premise was that the nine photographers whose work he had assembled represented the American landscape in ways that amounted to a paradigm shift away from the romantic sublime toward a more impersonal, bland objectivity.

The term 'New Topographics' was an ironic gesture to the earlier documentary realism of the topographical survey photography deployed in the service of the Pacific Railroad and US Geological Surveys in the nineteenth century. The focus on 'man-altered landscape' involved such juxtapositions as:

tract houses seemingly constructed in the middle of nowhere; a drive-in movie screen silhouetted against Pike's Peak and even blending in with the latter's profile; roadways, road-kill, and burning oil sludges. New Topographics photography questioned the supposed distinction between cultural and natural landscapes.

(Dennis, 2005/2012:2)

It is difficult to exaggerate the influence of this approach on the subsequent course of landscape photography. Brisman's (2017) essay discusses this legacy through a detailed examination of the exhibition, 'Human-Altered Landscapes', exhibited at the Cincinnati Art Museum in 2015 and organized to coincide with the 40th anniversary of the 1975 'New Topographics' exhibition. The next section discusses some further photographic responses to the landscape tradition I have summarised here, indicating something of the range of social critique now to be found in them.

\section{Exposures}

One important strand of work has sought to replicate the geological survey photography of the nineteenth century. Especially significant here is Timothy O'Sullivan, whose images were taken initially for the military to survey the uncharted interior of the continent (unknown, that is, to non-Native Americans) in the 1860s through to the civilian geological surveys of the 1870s. It was Ansel Adams who led the calls for his survey photography to be recuperated into modernist canon in the 1930s, especially O'Sullivan's (1873) 'Ancient Ruins in the Canon de Chelle, New Mexico' (Figure 2), <Figure 2 near here> which he replicated in a similar composition in 1941 from practically the same spot and time as the original picture. The Rephotographic Survey Project was formed in 1977 to make replicas of the earlier 
nineteenth-century images, but unlike Adams, the project focused on documenting the changes that had occurred over the intervening century and highlighting the subjective decisions deployed by the earlier photographers in their visual craft. The Rephotographic Survey Project captures the impact of time on the landscape in nuanced ways:

many of the rephotographs documented egregious examples of land transformation resulting from western expansion, still others depicted landscapes seemingly untouched, still too remote for human impact. And, not infrequently, the Rephotographic Survey Project documented nature's reclamation of abandoned efforts at habitation or industrialization, or revealed other palimpests of failed $19^{\text {th }}$-century ventures largely effaced by time and land.

(Dennis, 2015:12, emphasis in original)

The aim, then, is one of exposure, probing what can be known and seen, the limits of which have been explored more recently by the geographer and artist Trevor Paglen.

Indeed, a third incarnation of the image of the canyon and ruins appeared in 2010 when Paglen included it in a diptych entitled 'Artifacts (Anasazi Cliff Dwellings, Canyon de Chelly; Spacecraft in Perpetual Geosynchronous Orbit, 35,786 km Above Equator)'. In the text accompanying the work, he explains that Anasazi is a Navajo term for 'ancient ones' or 'ancient enemies' and the cliff dwellings seem to have functioned as both shelter from the desert heat and as protection from invading enemies. They disappeared from the Southwest around 1100 C.E., leaving few clues as to why and many hundreds of years before more contemporary tribes moved to the area. In the eighteenth century, Spanish colonists arrived in the canyon, converting and killing the Navajo who lived there. The photograph is juxtaposed with a more abstract image composed of faint grey streaks, slanting down from left to right, set against a dark background punctuated by small, bright dots and marks moving against the overall pattern (Figure 3) <Figure 3 near here>. The effect has been described as follows:

The hazy, diagonal lines visually echo the shade, and mirror the direction, of the bands slanting down the cliff from right to left in the canyon photograph. The smaller, brighter marks also resonate with the other photograph, rhyming with the man-made shapes of the ruins' walls and windows, which interrupt the natural geometries of cliff ledge and canyon.

(Belisle, 2013:146)

The image is a long-exposure photograph of the night sky above the equator, the long streaks are stars, and the bright marks are satellites that 'will remain in orbit in virtual perpetuity' (www.paglen.com). Since the 1960s, hundreds and thousands of objects have been launched into space, many of which are now defunct but are destined to stay there as a belt of debris. This distant layer of debris will become the major ruins of our times, potentially drifting around the earth for billions of years, outlasting the great pyramids of Giza and the cave paintings of Lascaux. The correspondence between the images alludes to surveillance and conquest, the repetition of colonial invasion and its manifestation in the space race, as well as the mysterious, shifting scales of time, space and visibility that challenge anthropocentric sensibility.

Over the last two decades, Paglen has been investigating the shadow state through the 'trope of displacement', frequently blurring 'the lines between art and evidence' so that as his work has unfolded it has become 'an eclectic compendium of the aesthetic styles of the American 
landscape tradition' (Gustafsson, 2013:150). The topics addressed include data collection, military surveillance, drone warfare and the systems of power connected to them. It comprises images of secret military installations and restricted government areas, as well as painstakingly tracking the dozens of CIA-chartered planes used for extraordinary rendition to open a window into the dark worlds of state secrecy and the surrounding spying network. A further example of his work is a photo essay by Paglen (2014) of a drone series set against abstract, celestial skyscapes. In the essay introducing the eerie pictures, Guihot (2014:56 notes how:

\begin{abstract}
His art is not about "exposing" a truth, even if it makes visible what was not supposed to be seen; in fact, Paglen seems to be a fan of underexposure. Rather, he is interested in the sensorial and, one is tempted to say, existential experience of living in a securitized world, in the range of feelings one experiences when sensing the unsettling presence of a security apparatus woven into the texture of everyday life and into natural landscapes, hardly visible yet breaching our field of consciousness.
\end{abstract}

Paglen (2013:207) maintains that his concern is with 'how the political geographies that structure our everyday lives are becoming more and more abstract, and about how new forms of domination arise in the gaps and limits of our everyday perception'.

In this project, Paglen explores the communications satellites orbiting the earth and the development of stealth programs designed to interfere with space technology and disable their operations in such a way that it would be hard for someone else to know they had been sabotaged, making it appear as if they had simply failed. These efforts to control the orbital infrastructure are part of a systemic military strategy that he equates with 'switching cities off' (Graham, 2010:263). More recently, Paglen's (2016) attention has turned to the rise of 'machine vision' in digital media and the profound implications that flow from this transformation, enabling the exercise of power on much larger, and smaller, scales than ever before. Our built environments are increasingly filled with machine-to-machine seeing technologies, so that images no longer simply represent, but actively intervene in daily life in unseen ways. The work reveals how surveillance and pre-emptive war are being waged constantly over our heads and before our very eyes.

Returning to Cosgrove's (2001) arguments on the 'Apollonian gaze', it is clear that the 'God's eye' view has become crucial to warfare. Rey Chow (2006:31) has suggested 'that in the age of bombing, the world has also been transformed into-is essentially conceived and grasped as - a target'. The centrality of the 'overhead image' to thinking through this concept of 'the world as target' has been developed since by Lisa Parks $(2013,2016)$ in a compelling account of the frequency with which such imagery now circulates in our global media culture. The proliferation of such imagery relates to a combination of factors, ranging from the commercialization of satellite and remote sensing technologies to the transformation of the Internet into a location-based web system, mobilising consumer subjects into 'militarized ways of being' (Kaplan, 2006:708). As Parks (2013:197) defines it:

the overhead image refers to image-data that has been acquired by instruments onboard aircraft or satellites, downlinked to earth stations, rendered by computer software, and, in some cases, composited for the purposes of representing, viewing, and analyzing particular sites or activities on earth. The production of the overhead image is made possible by a vast and largely invisible 
communication infrastructure, which, I would argue, undergirds the capacity to imagine the world as a target.

The notion of the world target - the use of overhead imagery and networks of remote platforms-alerts us to how military-turned-consumer technologies are structuring our everyday lives in more abstract and increasingly pervasive ways, resonating with Paglen's various attempts to track this hidden world through the language of landscape art. Such imagery and networks also correspond with what Eyal Weizman (2007) has called the 'politics of verticality', which he has written about in the context of the Israeli occupation of Gaza, as well as with Nicholas Mirzeoff's (2011) account of 'oversight' in the transantlantic slave trade, where both authors explicitly consider the relationship between authority, authorized views and the production of landscape. Likewise, Tyler Wall and Tobin Monahan (2011:250) have developed the concept of 'drone stare' to describe a type of surveillance (and killing) that 'abstracts targets from political, cultural, and geographical contexts, thereby reducing variation, difference, and noise that may impede action or introduce moral ambiguity' ${ }^{1}$.

\section{Viewpoints}

So far, I have been discussing landscape representation through a North American tradition. In this section, I turn to European approaches that offer differing viewpoints on the tendencies discussed above. In Britain, landscape photography continued to concentrate on depicting exemplary images of rural harmony, timeless tranquillity and social unity. Roger Fenton's photographs provide the definitive statement on Victorian attitudes to landscape. His Mill at Hurst Green (1859) has been described as a 'postcard for the nineteenth century', portraying a cosy, rural village scene where there is 'no evidence of work, nor of poverty and hardship' (Clark, 1997:56) in ways that pay homage to the picturesque aesthetic of landscape painting (Figure 4) <Figure 4 near here>. These well-established conventions set out to instruct the viewer and tourist 'how to look at the natural landscape as an ordered, coherent pictorial whole rather than as a chaotic collection of bits and pieces' (Bermingham, 2002:86), confirming a conservative vision of social life and suppressing any sense of actual, lived experience. For much of the twentieth century, British landscape photography stuck to these terms of reference, but political control over colonial territory was a major preoccupation and mapping surveys provide further insights into the appropriation of landscape.

Although maps existed well before the rise of empires, the practice of mapping was bound up with the Enlightenment project of cataloging scientifically the world to make it more governable (Scott, 1999). For several centuries, it has been known that depicting a spherical surface on a flat page will inevitably produce certain kinds of distortion (Synder, 1993). Although maps have traditionally been seen as objective, scientific exercises in measuring accurately the 'lay of the land', more critical analyses have interrogated their cultural subjectivity. One excellent example is Angèle Smith's (2003:74) account of the British Ordnance Survey's intensive mapping project of the whole of Ireland from 1824 onward in which she notes how earlier mapping operations tended to accompany military action leading to "vast land clearances, and the re-writing of the landscape to make it "British space"". This project was unprecedented for the level of detail deemed necessary and unusually was not part of a land clearance effort, but it required an army of red-coated soldier-surveyors to document the landscape and their prolonged presence would have been a daily reminder of colonial rule. The maps were made by and for imperial power, but the political project was only partially successful, and Smith demonstrates how various struggles between British 
colonialism and Irish nationalism were subsequently played out through them. The colonial transformation of global property relations has occurred in multiple ways, but it is the surveyor as 'the point men of British imperialism' (Edney, 1993:62) who established the survey as one of the most powerful techniques of securing order over 'new territory' (see also Blomley, 2003:128).

Indeed, the fact that the British were able to rule large parts of the world with comparatively little military might has been explained through their extraordinary ability to grasp systems of information collection-manifest in its passion for inventories, lists, maps and pictures. Often 'they could do little other than collect and collate information, for any exact civil control, of the kind possible in England, was out of the question. The Empire was too far away, and the bureaucrats of Empire had to be content to shuffle paper' (Richards, 1993). Smith's discussion reveals how the maps were later caught up in struggles between colonialism and nationalism. Likewise, an important development in photographic studies of landscape has been an exploration of the connections forged between place, identity and belonging in ways that are culturally specific.

Such concerns can be seen in the following discussion of how landscape imagery offers distinct mediations on past and present:

Norwegian landscape photography tends to dramatise the mountains and fjords of the north. Nineteenth- and early twentieth-century Norwegian landscape painting and photography is clearly influenced by the Kantian sublime (best typified by the German painter Casper David Friedrich). The Norwegian mountain became a national icon - especially prominent at the turn of the century when Norway was seeking independence from Swedish rule. In effect the mountain for Norwegians became an equivalent to the Wordsworth country of the Lake District for Englishness. Thus when contemporary Norwegian photographers focus upon a more ordinary, everyday landscape such as lands used for recreation close to urban and suburban spaces, there is an implicit questioning of the myths of Norwegianness.

(Wells, 2009:307)

Similar themes have been pursued by more recent landscape photographers in Britain, especially in the work of Fay Godwin (1985), who builds a picture of the country as ancient, desolate terrain. It is a Britain of rugged upland, standing runes and stones, moorland edges and salt marshes, often juxtaposing modern and primeval relics, almost as if she is reporting from some mysterious, long abandoned country. Her work on land, access and property rights is informed by ecological movements in the 1970s and 1980s, which echoes efforts of her contemporaries to bring a sharper political focus to the tradition (see Figure 5). <Figure 5 near here>

Examples of this more critical approach include Ingrid Pollard's Pastoral Interludes exhibition, which confronts the implicit racialisation of landscape imagery. By taking the English countryside as her subject, her photographs and text bring 'race' and 'nation' together in striking ways to question 'dominant representations of black people within national history' (Kinsman, 1995:307) and asks what does it mean to feel 'at home' in the first place. In an image like John Davies's (1983) Agecroft Power Station, Pendlebury, Salford, Greater Manchester (Figure 6), <Figure 6 near here> there is a further deconstruction of English landscape mythology through a close chronicling of 
industrialisation and its aftermath. When Davies began in the early 1980s, many of these industries, and the communities created around them, were in terminal decline and the scene captured here is riven with a melancholic mood. From the football match playing out under the towering presence of smoking chimneys to the horse and cars occupying a derelict strip of land, where rural signifiers (trees, fence, stream, gate and path) are bare remnants of a 'natural' past, all the 'isolated details are subsumed into the scarred terrain' (Clarke, 1997:70). Yet, there is also a detached tone to the work, conveying some of the basic tenets of the 'new topographics' aesthetic, where the ambition was to capture the natural landscape as it had been altered by modern civilization.

Brisman (2017) has discussed the importance of this approach, where the key shift was away from the monumental toward the mundane, and the commonplace. There are two fundamental propositions in the 'new topographics' movement:

Firstly, the new generation of landscape photographers was concerned primarily with beauties found on the edge of town, at the junction between city and country, between man and nature. [Robert] Adams, for instance, photographed tacky suburban developments in Colarado, and Baltz the anonymity of industrial buildings in California. Secondly, in contrast to the expressiveness of previous photographic generations - such as Ansel Adams in the wilderness, or William Klein in the city - this group adopted a low-key, deliberately neutral style, as anonymous as real-estate photography or Victorian topographical work.

(Badger, 2014:150)

Pivotal were the German painters Bernd and Hilla Becher who began photographing industrial structures in the 1960s, in a deliberately affectless, typological technique and presenting the images in a standardised, grid form as if they were specimens or species. Their distinctive style is both clinical and conceptual, with very little variation, and is a mode of presentation that successive generations of students taught by them at the Düsseldorf Art Academy have pursued. Among the most significant is Andreas Gursky, whose work explores the fragile relationships between globalization, human beings and the environment. He makes photographs so large and brimming with detail that they aspire to a digitally driven reinvention of the medium and are aimed at the epic scale of grand painting.

Gursky has frequently set records for the highest prices achieved at auction for a photograph, including Rhein II, (1999, remastered 2015) transforming the famous river into a contemporary minimalist symbol (Figure 7). <Figure 7 near here> Significant elements have been digitally removed, not least a coal power station, leaving only narrow bands of sky, water and manicured grass that resembles post-war abstract art painting in colour, space and form. He has made no secret of how his images are digitally created composites and their 'fictional' quality is meant to convey more than simply the notion of a constructed image manipulated by digital techniques, but refers to how he builds up a picture like a painter or a writer of a scene. Such an account is typical of the way contemporary photographic artists describe 'their practice in order to legitimize it in art market terms' (Badger, 2010:237). Gursky's importance here, however, is not just due to his commercial and critical success, but to how he presents new ways of seeing the world. His key innovation is one that revels in repeated patterns, along with a frequent use of an elevated, distant viewpoint to chronicle the reach of global capitalism, where nothing is as it initially seems. 
Exemplary in this regard is his recent image, Amazon (2016), capturing the endless shelves of an enormous warehouse owned by the company, where tens of thousands of consumer objects-from books and kitchen appliances to toys and sporting goods-are amassed in no discernible order. This seemingly sprawling chaos is due to the digital coding system Amazon uses to manage its inventory, rather than a more conventional classification of products by category. The image provides an astonishing sense of the algorithmic visual order that is crucial to the online behemoth's success, but leaves a lasting impression of dismay at the consumer excess on display. It is in this sense that landscape photography has become political, for while these images are strangely alluring, they also reveal what cannot be seen easily and offer up complex depictions of place.

\section{Conclusion}

It has been said that landscape photography is awash with cliché, and in this paper, I have concentrated on photographers who have worked in, against and around the conventions of commodity spectacle associated with advertising imagery and tourist marketing. Many are versed fully in the terms by which scenes are reduced to stereotypical, picture postcard views and have sought to subvert them while remaining aesthetically resonant. Some can be subtle studies of a place and its history, but the 'role of aestheticization is the most difficult issue within the issue of communicating not only how the landscape looks, or seems, but how it is' (Lippard, 1997:182, emphasis in original). Under these circumstances the geographical arguments introduced earlier in the paper are crucial in grappling with these difficulties. In an interview, Paglen has commented on their importance:

I think a lot of artists see in geography the same thing that got me initially interested in the field: geography provides a far more robust theoretical framework for understanding landscape than more conventional art traditions. As "landscape" in art has moved far outside the frames of painting and photography, a lot of artists are turning towards geography for methodological and analytical inspiration. I really hope that more geography departments become open to the idea of having MFAs (Master of Fine Arts degree) come in for PhD work. There's just a huge amount of interest in our field from artists, and I think geographic ideas could really become influential in the arts. Obviously, I also think geographers have a lot to learn from artists.

(quoted in Dear, 2011:24)

These points also extend to criminology, and have implications for the study of environmental crime and harm, not least because a key geographical insight is that the border between nature and culture should never be drawn sharply. As I suggested at the start of this paper, one of the defining achievements of green criminology has been to pose important questions on these relations and it is no accident that Raymond Williams (1976) considers 'nature' as the most complex word in the English language ('culture' runs it a close second or third). Much of the difficulty is precisely because the idea is so fundamental to human identity.

Indeed, the main conclusion that can be gleaned from a close look at landscape photography is that in "photographing place, we are never just photographing nature. We are always photographing culture' (Badger, 2014:154, emphasis added). Clearly, the photography of place has a long and complex tradition, and some of the leading contemporary landscape photographers have developed a distinctive set of strategies to address this past and revitalise 
the present. The best manage to achieve what Lucy Lippard (1997:7), in a book that is strongly informed by the cultural geographers discussed above, refers to as the 'lure of the local' - the 'multicentred' senses of place-how the 'intersections of nature, culture, history, and ideology form the ground on which we stand'. Her argument is that a sense of place is what ties humans, culture and the environment together and that place must be felt emotionally to make any sense.

This paper has sought to address some of these geographies of landscape and indicate how there is a rich strain of photography encouraging us to wonder how places come into being, how environmental and social forces work over them, and indeed how to think of landscapes as work. Inevitably, I have barely scratched the surface of what is rich terrain, but what I hope to have shown are further areas for green criminology to explore as it enlarges the discipline's field of vision.

\section{Acknowledgements}

I would like to thank the two anonymous reviewers for their helpful comments on the initial version of this paper, as well as the guest editors of this special issue for all their assistance. All the images have been reproduced with permission from the copyright holders and thanks are due to ... for their help in securing them.

\section{Funding}

This work was supported by a Leverhulme Trust Major Research Fellowship, MRF-2014052.

\section{References}

Adams, Ann (2002) 'Competing Communities in the "Great Bog of Europe": Identity and Seventeenth-Century Dutch Landscape Painting', in Mitchell, W.J.T. (ed.) Landscape and Power, Chicago: University of Chicago Press.pp.35-76. $2^{\text {nd }}$ edition.

Badger, G. (2010) The Pleasure of Good Photographs, New York: Aperture.

Badger, G. (2014) The Genius of Photography: How Photography has Changed our Lives, London: Quadrille.

Belisle, B. (2013) 'Artifacts: Trevor Paglen's Frontier Photography', in Kruse, J. and E. Elsworth (eds.) Making the Geologic Now: Responses to Material Conditions of Contemporary Life, Brooklyn, NY: Punctum. Pp. 145-149.

Bermingham, A. (2002) 'System, Order, and Abstraction: The Politics of English Landscape Drawing around 1795', in Mitchell, W.J.T. (ed.) Landscape and Power, Chicago: University of Chicago Press.pp.77-101. $2^{\text {nd }}$ edition.

Blaut, J. (1993) The Colonizer's Model of the World, New York: Guilford Press.

Blomley, N. (2003) 'Law, Property, and the Geography of Violence: The Frontier, the Survey, and the Grid', in Annals of the Association of American Geographers, 93(1):121-141. 
Bright, D. (1985) 'Of Mother Nature and Marlboro Men: An Enquiry into the Cultural Meanings of Landscape Photography', in Exposure 23(1), revised reprint in Bolton, R. (ed.) The Contest of Meaning, Cambridge, MA: The MIT press, pp.125-143.

Bright, D. (1992) 'The Machine in the Garden Revisited: American Environmentalism and Photographic Aesthetics', in Art Journal, 51(2):60-71.

Brisman, A. (2010) 'The Indiscriminate Criminalisation of Environmentally Beneficial Activities', in White, R. (ed.) Global Environmental Harm: Criminological Perspectives, Cullompton, Devon, UK: Willan.

Brisman, A. (2017) 'Representations of Environmental Crime and Harm: A Green Cultural Criminological Perspective on Human-altered Landscapes', in Brown, M. and E. Carrabine (eds.) The Routledge International Handbook of Visual Criminology, London: Routledge. Pp. 523-539.

Brisman, A. and South, N. (2013) A green-cultural criminology: An exploratory outline. Crime Media Culture 9(2): 115-35.

Brisman A and South N (2014) Green cultural criminology: Constructions of environmental harm, consumerism, and resistance to ecocide. London and New York: Routledge.

Brown, M. and E. Carrabine (eds.) (2017) Routledge International Handbook of Visual Criminology, London: Routledge

Carrabine, E. (forthcoming' 'Traces of Violence: Representing the Atrocities of War', in Criminology and Criminal Justice

Chow, R. (2006) The Age of the World Target: Self-Referentiality in War, Theory, and Comparative Work, Durham, NC: Duke University Press.

Clark, G. (1997) The Photograph, Oxford: Oxford University Press.

Cosgrove, D. (1988/2008) 'Geography is Everywhere: Culture and Symbolism in Human Landscapes', in Oakes, T. and P. Price (eds.) The Cultural Geography Reader, London: Routledge, pp.177-185.

Cosgrove, D. (1998/2008) 'Introduction to Social Formation and Symbolic Landscape', in R. Z. DeLue and J. Elkins (eds.) Landscape Theory, London: Routledge, pp.17-42.

Cosgrove, D. (2001) Apollo's Eye: A Cartographic Genealogy of the Earth in the Western Imagination, Baltimore, MD: John Hopkins University Press.

Cunneen, C. and J. Tauri (2016) Indigenous Criminology, Bristol: Policy Press.

Dear, M. (2011) 'Experimental Geography: An Interview with Trevor Paglen, Oakland, CA, February 17, 2009', in Dear, M., J. Ketchum, S. Luria and D. Richardson (eds.) GeoHumanities: Art, History, Text at the Edge of Place, Londond: Routledge. 
Dennis, K. (2005/2012) 'Landscape and the West - Irony and Critique in New Topographic Photography' available at http://www.americansuburbx.com/2012/05/new-topographicslandscape-and-the-west-irony-and-critique-in-new-topographic-photography-2005.html.

Dennis, K. (2015) 'Eclipsing Aestheticism: Western Landscape Photography after Ansel Adams', in Miranda, 11:1-22.

Driver, F. (2000) Geography Militant: Cultures of Exploration and Empire, Blackwell: Oxford.

Edney, M. (1993) 'The Patronage of Science and the Creation of Imperial Space, 1799-1843: The British Mapping of India', Cartographica 30:61-7.

Ferrell, J. (2013) 'Tangled up in Green: Cultural Criminology and Green Criminology', in South, N. and A. Brisman (eds.) The Routledge International Handbook of Green Criminology, London and New York: Routledge.pp.349-364.

Godlewska,A. and N. Smith (eds.) (1994). Geography and Empire, Cambridge, MA: Blackwell.

Graham, S. (2010) Cities Under Siege, London: Verso.

Gustafsson, H. (2013) 'Foresight, Hindsight and State Secrecy in the American West: The Geopolitical Aesthetics of Trevor Paglen', in Journal of Visual Culture, 12(1):148-164.

Hayward, K. (2012). Five spaces of cultural criminology. British Journal of Criminology, 52(3):441-462.

Hopkins, P. and R. Pain (2007) 'Geographies of Age: Thinking Relationally', in Area, 39(3):287-294.

Horton, J. and P. Kraftl (2014) Cultural Geographies, London: Routledge.

Kaplan, C. (2006) 'Precision Targets: GPS and the Militarization of U.S. Consumer Identity', in American Quarterly, 58(3):693-714.

Kinsman, P. (1995) 'Landscape, Race and National Identity: The Photography of Ingrid Pollard', in Area, 27(4):300-310.

Krauss, R. (1982) 'Photography's Discursive Spaces: Landscape/View', in Art Journal, 42(4):311-319.

Lippard, L. (1997) The Lure of the Local: Senses of Place in a Multicentred Society, New York: New Press.

Mahtani, M. (2001) 'Racial reMappings: The Potential of Paradoxical Space', in Gender, Place and Culture, 8(3):299-305.

Matless, D. (1998) Landscape and Englishness London: Reaktion Books. 
Matless, D. (2014) In the Nature of Landscape: Cultural Geography on the Norfolk Broads, Oxford:Wiley-Blackwell.

Matless, D. (2017) 'The Anthroposcenic', in Transactions of the Institute of British Geographers. 42(3), 363-376.

Mirzoeff, N. (2011) The Right to Look: A Counterhistory of Visuality, Durham: Duke University Press.

Mitchell, D. (1996) Lie of The Land: Migrant Workers and the California Landscape, Minneapolis: University of Minnesota Press.

Mitchell, P. (2011) “"The Stratified Record upon which we set our Feet”: The Spatial Turn and the Multilayering of History, Geography, and Geology', in Dear, M., J. Ketchum, S. Luria, and D. Richardson (eds.) GeoHumanities: Art, History, Text at the Edge of Place, London: Routledge. Pp. 71-83.

Mitchell, W.J.T. (2002a) 'Imperial Landscape', in Mitchell, W.J.T. (ed.) Landscape and Power, Chicago: University of Chicago Press.pp.5-34. $2^{\text {nd }}$ edition.

Mitchell, W.J.T. (2002b) 'Preface to the Landscape and Power: Space, Place, and Landscape', in Mitchell, W.J.T. (ed.) Landscape and Power, Chicago: University of Chicago Press.pp.5-34. $2^{\text {nd }}$ edition.pp.vii-xii.

Moran, D. (2015) Carceral Geography: Spaces and Practices of Incarceration, London: Routledge.

Nash, C. 'Performativity in Practice: Some Recent Work in Cultural Geography', in Progress in Human Geography, 24(4): 653-664.

Natali, L. (2016) A Visual Approach for Green Criminology: Using Photo Elicitation to Explore the Social Perception of Environmental Harm, London: Palgrave.

Paglen, T. (2009) Blank Spots on the Map: The Dark Geopgraphy of the Pentagon's Secret World, New York: Dutton.

Paglen, T. (2010) Invisible: Covert Operations and Classified Landscapes, New York: Aperture.

Paglen, T. (2012) The Last Pictures, New York: Creative Time.

Paglen, T. (2013) 'What Greg Roberts Saw: Visuality, Intelligibility, and Sovereignty $30,600 \mathrm{~km}$ over the Equator', in Mirzoeff, N. (ed.) The Visual Culture Reader, London: Routledge.pp.207-219.

Paglen, T. (2014) 'Geographies of Photography'. Blogpost published on 11.04.2014available at https://www.fotomuseum.ch/en/explore/still-searching/articles/26980, accessed 07.27.2017. 
Paglen, T. (2016) 'Invisible Images (Your Pictures Are Looking at You)', in Science/Fiction, $74: 14-22$.

Parks, L. (2013) 'Zeroing In: Overhead Imagery, Infrastructure Ruins, and Datalands in Afghasnistan and Iraq', in Mirzoeff, N. (ed.) The Visual Culture Reader, London: Routledge.pp.196-206.

Parks, L. (2016) 'Drones, Vertical Mediation, and the Targeted Class', in Feminist Studies 42(1):227-235.

Richards, T. (1993) The Imperial Archive: Knowledge and the Fantasy of Empire, London: Verso.

Rose, G. (1993) Feminism and Geography, Minneapolis: University of Minnesota Press.

Schept, J. (2015) Progressive Punishment: Job Loss, Jail Growth, and the Neoliberal Logic of Carceral Expansion, New York: New York University Press.

Scott, J.C. (1999). Seeing like a state: How certain schemes to improve the human condition have failed. New Haven, CT: Yale University Press.

Sekula, A. (1981) 'The Traffic in Photographs', in Art Journal 41(1):15-25.

Shalhoub-Kevorkian, N. (2017) 'The Occupation of the Senses: The Prosthetic and Aesthetic of State Terror', in British Journal of Criminology, 57(6):1279-1300.

Smith, A. (2003) 'Landscape Representation: Place and Identity in Nineteenth-century Ordnance Survey Maps of Ireland', in Stewart, P. and A. Strathern (eds.) Landscape, Memory and History: Anthropological Perspectives, London: Pluto Press.

Snyder, J. P. (1993). Flattening the earth: Two thousand years of map projections. Chicago: University of Chicago Press.

Snyder, J. (2002) 'Territorial Photography', in Mitchell, W.J.T. (ed.) Landscape and Power, Chicago: University of Chicago Press.pp.5-34. $2^{\text {nd }}$ edition. pp.175-201.

Sollund, R. (2017) 'The Animal Other: Legal and Illegal Theriocide', in Hall, M., T. Wyatt and N. South (eds.) Greening Criminology in the $21^{\text {st }}$ Century: Contemporary Debates and Future Directions in the Study of Environmental Harm, London: Routledge.

Story, B. (2016) dir, The Prison in Twelve Landscapes. Toronto, ON: Oh Ratface Films.

South, N. (1998) 'A Green Field for Criminology', in Theoretical Criminology, 2(2):211-34.

Spaulding, J. (1998) Ansel Adams and the American Landscape: A Biography, Los Angeles: University of California Press.

Wall, T. and T. Monahan (2011) 'Surveillance and Violence from Afar: The Politics of Drones and Liminal Security-scapes', in Theoretical Criminology, 15(3) 239 -254. 
Weizman, Eyal (2007) Hollow Land: Israel's Architecture of Occupation. London: Verso.

Wells, L. (2009) 'On and Beyond White Walls: Photography as Art', in Wells, L. (ed.) Photography: A Critical Introduction, London: Routledge. Pp.257-310.

White, R. (2002) 'Environmental Harm and the Political Economy of Consumption', in Social Justice, 29(1-2):82-102.

Williams, R. (1976) Keywords, London: Fontana.

Wylie, J. (2007) Landscape, London: Routledge. 
Figure 1 William Henry Jackson (1883) 'Grand Canyon of the Colarado River'.

Image to be supplied separately.

Credit line: Digital image courtesy of the Getty's Open Content Program.

Figure 2 Timothy O’Sullivan (1873) 'Ancient Ruins in the Canon de Chelle, New Mexico'.

Image to be supplied separately.

Credit line: Digital image courtesy of the Getty’s Open Content Program.

Figure 3 Trevor Paglen (2010) 'Anasazi Cliff Dwellings, Canyon de Chelly, Spacecraft in Perpetual Geosynchronous Orbit, 35,786 km Above Equator’. C-Print, $40 \times 50$ inches.

Image to be supplied separately.

Credit line:@ Trevor Paglen, Courtesy of the Artist, Metro Pictures New York, Altman Siegel San Francisco.

Figure 4 Roger Fenton (1858) 'Mill at Hurst Green.'

Image to be supplied separately.

Credit line: Royal Photographic Society/Science \& Society Picture Library.

Figure 5 Fay Godwin (1990) 'Duke of Westminster's Estate; Forest of Bowland'.

Image to be supplied separately.

Credit line: () The British Library Board.

Figure 6 John Davies (1983) 'Agecroft Power Station, Pendlebury, Salford, Greater Manchester'.

Image to be supplied separately.

Credit line: (C) John Davies. All Rights Reserved, DACS/Artimage 2018.

Figure 7 Andreas Gursky (1999) 'Rhein II'.

Image to be supplied separately. 
Credit line: (C) Andreas Gursky, VG BILD-KUNST, Bonn. Courtesy Sprüth Magers Berlin London/ DACS 2018.

\footnotetext{
${ }^{1}$ I am grateful to one of my reviewers for reminding me of the relevance of Nicholas Mirzoeff's, Eyal Weitzman's, and Tyler Wall and Tobin Monahan's work here, while introducing me to Nicholas Blomley's scholarship - who underlines the ties between property, violence and space-in ways that demand further explication than I can provide here.
} 